\title{
PENGARUH PERKEMBANGAN ZAMAN \\ TERHADAP PERGESERAN TATA BAHASA INDONESIA; STUDI KASUS PADA PENGGUNA INSTAGRAM TAHUN 2018
}

\author{
Dewi Rani Gustiasari \\ Universitas Pamulang \\ email : dewirani.gustiasari@gmail.com
}

Paper Accepted: 30 Juni 2018 Paper Reviewed: 7-15 Juli 2018 Paper Edited: 17-24 Juli 2018 Paper Approved: 25 Juli 2018

\begin{abstract}
ABSTRAK
Bahasa adalah identitas dari suatu negara ataupun wilayah yang digunakan sebagai alat komunikasi utama.Setiap orang membutuhkan bahasa ketika berinteraksi, mengungkapkan ide dan pendapat serta hubungan sosial lainnya.Jejaring sosial merupakan media yang banyak digunakan para penutur bahasa untuk berkomunikasi jarak jauh melalui internet. Dalam perkembangannya pemakaian bahasa Indonesia mulai bergeser digantikan dengan pemakaian bahasa anak remaja yang disebut bahasa gaul. Penggunaan kosakata bahasa gaul pada salah satu jejaring sosial yaitu instagram terus berkembang dan berganti mengikuti tren. Pemakaian bahasa gaul tidak hanya dipakai oleh remaja, tak jarang orang berpendidikan pun menggunakan bahasa gaul ini, baik dalam bentuk lisan maupun tulisan, baik dalam waktu formal maupun non formal mengakibatkan penggunaan bahasa menjadi tidak baik dan tidak benar. Alangkah baiknya bila kita dapat menggunakan bahasa Indonesia yang baik dan benar, sehingga keberadaan bahasa Indonesia sebagai bahasa nasional tetap terjaga. Bahasa Indonesia adalah bahasa persatuan, jadi sebagai masyarakat Indonesia yang peduli dan menghormati bahasa nasionalnya, kita harus menjaga serta turut melestarikan bahasa kita yaitu bahasa Indonesia. Apabila kita sudah menggunakan bahasa Indonesia yang baik dan benar maka secara langsung orang yang berada di sekitar kita akan tertular.
\end{abstract}

Kata Kunci: bahasa gaul, jejaring sosial

\section{PENDAHULUAN}

\section{Latar Belakang}

Tidak semua warga negara Indonesia bisa menggunakan bahasa Indonesia yang baik dan benar, begitupula dengan kalangan remaja. Tujuan bahasa Indonesia yang baik dan benar adalah mengajarkan dan menerangkan tentang penggunaan bahasa Indonesia dalam kehidupan sehari-hari agar tidak terlalu menyimpang dari kaidah bahasa Indonesia yang baik dan benar, serta melestarikannya sebagai warisan bangsa yang merupakan bahasa Indonesia yang baik dan benar yang sudah ada sejak indonesia mardeka.

Bahasa merupakan unsur yang sangat penting dalam berkomunikasi, yaitu sebagai alat komunikasi yang paling utama. Seiring dengan perkembangan zaman, pemakaian bahasa Indonesia yang baik dan benar dalam kehidupan sehari-hari mulai bergeser oleh pemakaian bahasa anak remaja yang dikenal dengan bahasa gaul. Sehubungan dengan itu, perlu adanya tindakan dari semua pihak yang peduli terhadap bahasa Indonesia.Penggunaan bahasa yang baik dan benar dapat mempermudah dalam menyampaikan informasi.Sehingga orang terbiasa untuk berkomunikasi secara lebih efektif.

Penggunaan bahasa Indonesia yang baik dan benar sangat penting untuk diketahui oleh para remaja. Hal ini supaya bahasa Indonesia yang merupakan bahasa nasional, bahasa persatuan, dan bahasa pengantar dalam dunia 
pendidikan bisa tetap ada dan tidak kalah eksistensinya oleh bahasa gaul.

Penggunaan bahasa gaul yang semakin banyak dikalangan remaja membuat eksistensi bahasa Indonesia menjadi menurun. Oleh karena itu, pengaruh bahasa gaul terhadap penggunaan bahasa Indonesia yang baik dan benar di kalangan remaja harus mendapat perhatian.

Pada penulisan makalah ini penulis memfokuskan pembahasan mengenai pengaruh bahasa gaul terhadap penggunaan bahasa Indonesia yang baik dan benar di kalangan remaja. Penulis membatasi masalah yang akan dibahas dalam makalah ini yaitu, bentuk bentuk pergeseran kata yang terjadi pada pengguna instagram tahun 2018. Berdasarkan fokus masalah tersebut, maka perumusan masalah dalam makalah ini adalah bagaimana pengaruh bahasa gaulterhadap perubahan kata pengguna instagram, bagaimana bentuk bentuk pergeseran kata dalam penggunaan instagram, dan implikasi pergeseran kata yang di gunakan dalam instagram.

\section{METODE PENELITIAN}

Metode penelitian yang digunakan dalam penelitian ini adalah metode deskriptif kualitatif. Metode deskriptif karena peneliti berusaha meyajikan kenyataan-kenyataan secara objektif sesuai dengan kenyataan yang ditemukan di lapangan tentang penggunaan bahasa gaul dalam media sosial Instagram. Metode kualitatif karena peneliti berusaha menguraikan fakta atau fenomena penggunaan bahasa gaul dalam bentuk kata.

Jenis penelitian ini tergolong penelitian lapangan peneliti mengamati Penggunaan bahasa gaul oleh remaja di dalam interaksi di dunia maya melalui aplikasi media sosial Instagram.

Data dalam penelitian ini adalah data tulis dari pembaharuan status dan komentar oleh remaja yang menggunakan bahasa gaul dalam interaksi di media sosial Instagram data diperoleh dari hasil observasi. Sumber data dalam penelitian ini adalah remaja yang memperbaharui status dan berkomentar di Instagram.

Dalam penelitian ini, peneliti sebagai instrumen kunci dan menggunakan alat bantu berupa smartphone sebagai sarana penghubung dalam mengamati fenomena bahasa gaul yang digunakan dalam interaksi di media sosial Instagram.

Teknik pengumpulan data yang digunakan dalam penelitian ini adalah sebagai berikut :
1. Teknik observasi ini digunakan agar peneliti dapat mengamati dengan bebas, sehingga diharapkan hasil penelitian ini akan obyektif. Di dalam penelitian ini menggunakan observasi non partisipan. Observasi non partisipan adalah dimana observer tidak ikut di dalam kehidupan orang yang akan diobservasi, dan secara terpisah berkedudukan selaku pengamat. Di dalam hal ini observer hanya bertindak sebagai penonton saja tanpa harus ikut terjun langsung ke lapangan.Observasi adalah metode pengumpulan data melalui pengamatan langsung atau peninjauan secara cermat dan langsung di lapangan atau lokasi penelitian.Dalam hal ini, peneliti dengan berpedoman kepada desain penelitiannya perlu mengunjungi lokasi penelitian untuk mengamati langsung berbagai hal atau kondisi yang ada di lapangan.

2. Teknik baca yaitu dengan membaca setiap status dan komentar informan yang diketik dan diunggah ke dalam media sosial instagram.

3. Teknik dokumentasi dengan memfoto status dan komentar informan melalui layar smartphone. Untuk mendapatkan bahasa tulis yang merupakan bahasa gaul.

Analisis data dalam penelitian ini menggunakan analisis sosiolinguistik yaitu ilmu yang mengkaji pengaruh budaya terhadap cara suatu bahasa digunakan. Dalam hal ini bahasa berhubungan erat dengan masyarakat sebagai subjek atau pelaku bahasa sebagai alat komunikasi dan interaksi antara kelompok. Dalam penelitian ini, akan dibahas gaya berbahasa remaja dalam media sosial instagram yang menggunakan bahasa gaul dalam interaksi tidak langsung melalui perantara akun instagram mereka.

\section{PEMBAHASAN}

\section{Pengaruh Bahasa Gaul Terhadap Perubahan Kata Pengguna Instagram}

Saat ini banyak sekali remaja yang menciptakan bahasa gaul, yaitu bahasa baku yang diubah, sehingga terkadang orang dewasa tidak memahami bahasa apa yang dikatakan oleh para remaja tersebut. Remaja cenderung lebih menyukai bahasa gaul dari pada menggunakan bahasa Indonesia yang baik dan benar. Supaya mereka lebih terlihat modern, dan 
akhirnya mulai lunturnya kecintaan pada bahasa Indonesia adalah hal yang harus dihindari.

Bahasa gaul dapat timbul dimana saja,. Bahasa yang digunakan oleh anak muda pada umumnya ini muncul dari kreativitas mengolah kata baku dalam bahasa Indonesia menjadi kata yang tidak baku. Bahasa gaul bisa ditemukan di mana saja, karena bahasa gaul dapat timbul di iklan televisi, lirik lagu remaja, novel remaja dan banyak lagi. Inilah kenyataan bahwa tumbuhnya bahasa gaul di tengah eksistensi bahasa Indonesia tidak dapat dihindari, ini karena pengaruh perkembangan alat komunikasi yang terus berkembang dan karena bahasa gaul dipakai anak muda kebanyakan maka bahasa baku akan tergeser eksistensinya. Apalagi dengan maraknya dunia kalangan artis menggunakan bahasa gaul dimedia sosial instagram, membuat remaja semakin sering menirukannya di kehidupan sehari-hari hal ini sudah menjadi wajar karena remaja suka meniru hal-hal yang baru. Inilah yang menjadi awal lunturnya bahasa Indonesia yang baik dan berganti dengan bahasa gaul.

Orang tua berkewajiban untuk mengajarkan penggunaan bahasa yang baik dan benar kepada anak sejak kecil.Penggunaan bahasa yang baik dapat mempermudah dalam menyampaikan informasi.Di dalam kehidupan sehari-hari seharusnya digunakan tata bahasa yang baik dan benar supaya masyarakat khususnya remaja terbiasa untuk berkomunikasi secara lebih efektif. Adanya bahasa gaul juga sangat mempengaruhi etika seseorang dalam berkomunikasi.

Kata-kata yang digunakan dalam berbicara seseorang dapat mencerminkan kemampuan berpikir dan tingkat kepribadiannya. Kepribadian seseorang yang baik dapat memilih apa saja yang harus diucapkan dan dibicarakan. Tidak berlebihan jika seseorang yang pandai berbahasa Indonesia, ia akan merasa diterima dan dihargai oleh berbagai kalangan. Ada beberapa solusi yang dapat meningkatkan penggunaan bahasa Indonesia yang baik dan benar yaitu, menyadarkan dan memotivasi remaja akan fungsi dan pentingnya bahasa yang baku. Selanjutnya, hal ini juga membutuhkan suatu upaya pembiasaan, artinya, remaja dilatih untuk berbahasa secara tepat, baik secara lisan maupun tulis setiap saat setidaknya selama berada di lingkungan sekolah. Pembiasaan ini akan sangat mempengaruhi perkembangan kemampuan berbahasa pada remaja. Proses penyadaran dan pembiasaan tidak kalah penting, hal ini akan menimbulkan keinginan remaja untuk mempelajari bahasa Indonesia yang baik dan benar.
Kekhawatiran akan semakin maaraknnya penggunaan bahasa gaul/alay pada media sosial tentulah beralasan. Bahasa gaul/alay dianggap sebagai ancaman yang serius terhadap kaidah tata bahasa Indonesia, karena meskipun dalamm dunia linguistik dikenal dengan bahasa baku dan tidak baku, bahasa alay adalah bahasa tidak baku yang tidak mengindahkan. Selain itu, sifat dari media sosial yang membuat penikmatnya asik dengan dunia maya mereka masing-masing membuat mereka malas berkomunikasi di dunia nyata.

Akibatnya, karena sering berinteraksi di media sosial dengan bahasa gaul / alay, tingkat pemahaman bahasapun akan terganggu.

Apabila hal ini dibiarkan terus-menerus dan tidak dilakukan penegahan, lama-lama bahasa gaul inipun akan bersifat arbiter. Hilanglah sudah keorsinilan bahasa ibu kita, bahasa Indonesia. Maka, untuk menghidari hal ini perlu adanya upaya untuk menanamkan dan menumbuhkan kecintaan terhadap pemahaman bahasa Indonesia. Salah satu upaya yang telah terbukti efektif adalah pendekatan pembelajaran bahasa Indonesia dengan menggunakan media sosial dalam membantu siswa memahami kaidah tata bahasa Indonesia yang baik dan benar. Selain media sosial sudah menjadi bagian dari kehidupan masyarakat Indonesia, terutama kaum remaja, upaya ini juga juga dilatarbelakangi fenomena remaja masa kini yang lebih banyak berinnteraksi di dunia maya.

\section{Pengertian Bahasa Indonesia yang Baik dan Benar}

Bahasa Indonesia ialah bahasa yang terpenting di kawasan republik kita. Dengan menggunakan bahasa indonesia secara baik dan benar, berarti kita telah menjunjung tinggi bahasa persatuan seperti yang diikrarkan dalam sumpah pemuda pada tanggal 28 Oktober 1928.

Perubahan bahasa dapat terjadi bukan hanya berupa pengembangan dan perluasan, melainkan berupa kemunduran sejalan dengan perubahan yang dialami masyarakat. Berbagai alasan sosial dan politis menyebabkan banyak orang meninggalkan bahasanya, atau tidak lagi menggunakan bahasa lain.

Kita sebagai warga Indonesia harus menggunakan bahasa Indonesia dengan baik dan benar. Maksud dari bahasa yang benar atau betul ialah pemakaian bahasa yang mengikuti kaidah yang dibakukan atau yang dianggap baku. Sedangkan bahasa yang baik atau tepat ialah pemanfaatan ragam yang tepat dan serasi menurut golongan penutur dan jenis pemakaian bahasa.Maka anjuran agar kita "berbahasa indonesia dengan baik dan benar" dapat 
diartikan pemakaian ragam bahasa yang serasi dengan sasarannya dan yang di samping itu mengikuti kaidah bahasa yang betul.Ungkapan "bahasa yang baik dan benar", sebaliknya, mengacu ke ragam bahasa yang sekaligus memenuhi persyaratan kebaikan dan kebenaran.

\section{Penggunaan Bahasa Indonesia di Media Sosial}

Bahasa merupakan instrumen terpenting dalam kehidupan manusia.Manusia tidak dapat hidup tanpa menggunakan bahasa, baik lisan maupun tulisan. Bahasa adalah simbol-simbol yang digunakan untuk menyatakan gagasan, ide, dan perasaan orang kepada orang lain. Mulai dari bangun tidur, makan, mandi, sampai tidur lagi, atau melakukan berbagai aktivitas manusia lainnya, tidak luput dari adanya penggunaan bahasa.

Bahasa gaul atau bahasa prokem adalah ragam bahasa Indonesia nonstandar yang lazim digunakan di Jakarta pada tahun 1970-an yang kemudian digantikan oleh ragam yang disebut sebagai bahasa gaul. Perkembangan teknologi di Indonesia sudah pesat.Tidak dapat dimungkiri, teknologi telah membawa dampak yang sangat besar terhadap kegiatan yang dilakukan seharihari seperti kegiatan belajar, bermain, berkumpul atau bersosialisasi, bertransaksi, dan berkomunikasi.Cara-cara manual dalam melakukan kegiatan tesebut sudah mulai ditinggalkan dan digantikan oleh teknologi.Akhirnya, hal tersebut membuat manusia tidak dapat dipisahkan dari perkembangan teknologi.

Di antara lima kegiatan yang telah disebutkan sebelumnya, kegiatan yang terkena dampak paling besar dari perkembangan teknologi adalah kegiatan berkomunikasi. Dahulu, berkomunikasi dilakukan dengan menggunakan surat dan komunikasi intrapersonal. Kelemahan dari cara berkomunikasi konvensional ini adalah diperlukannya biaya, waktu, dan tenaga yang banyak, contohnya ketika kita menggunakan surat untuk berkomunikasi dengan teman yang berbeda pulau ataupun negara, surat tersebut memerlukan waktu yang lama untuk sampai kepada teman kita. Namun, setelah berkembangannya teknologi, komunikasi dapat dilakukan dengan mudah, cepat, dan hemat, contohnya berkomunikasi menggunakan aplikasi Short Message Service (SMS) dan online chatting, seperti Whatsapp, Blackberry Messenger (BBM), INSTAGRAM dan LINE, yang sudah dipasang pada ponsel. Berbagai aplikasi tersebut dapat menghubungkan kita secara langsung dengan orang yang ingin kita hubungi. Dengan adanya teknologi, berbagai halangan, seperti jarak, waktu, dan biaya, tidak lagi dapat memengaruhi kita untuk dapat berkomunikasi dengan orang lain.

\section{Bahasa Gaul/Alay}

Pada masa sekarang, bahasa gaul banyak digunakan oleh kaula muda, meski kaula tua pun ada juga yang menggunakannya. Bahasa ini bersifat temporal dan rahasia, maka timbul kesan bahwa bahasa ini adalah bahasa rahasianya para pencoleng atau penjahat, padahal sebenarnya tidak demikian. Faktor kerahasiaan ini menyebabkan kosakata yang digunakan dalam bahasa gaul sering kali berubah. Para remaja menggunakan bahasa gaul ini dalam ragam lisan dan ragam tulis, atau juga dalam ragam berbahasa dengan menggunakan media tertentu, misalnya, berkomunikasi dalam jejaring sosial.

Jejaring sosial merupakan media yang banyak digunakan para penutur bahasa untuk saling berkomunikasi jarak jauh melalui internet.Jejaring sosial yang banyak diminati oleh masyarakat, yaitu facebook dan twitter. Dalam facebook dan twitter, para pengguna dapat menuliskan apa yang sedang dipikirkannya dalam "status" dan dapat saling memberikan komentar pada "kiriman" dan "status" rekan-rekan mereka. Selain itu, mereka juga dapat saling berdialog dan memberi komentar satu sama lain. Era globalisasi yang begitu marak terjadi di masa sekarang menyentuh semua aspek kehidupan, termasuk bahasa.

Bahasa Indonesia adalah bahasa resmi Republik Indonesia dan bahasa persatuan bangsa Indonesia. Bahasa Indonesia digunakan secara luas di perguruan-perguruan tinggi, media massa, sastra, surat-menyurat resmi, dan berbagai forum publik lainnya. Fungsi utama dari bahasa Indonesia adalah untuk menyatukan bangsa Indonesia dalam hal berkomunikasi. Namun kenyataannya, penggunaan bahasa Indonesia yang baik dan benar belum dilaksanakan secara maksimal, terutama dalam berkomunikasi sehari-hari, contohnya pada penggunaan bahasa ketika kita mengetikkan postingan di istagram. Mari kita lihat contoh berikut.

\section{Sampel dari 100 Sampel Percakapan di Instagram}

pict-001 ... wulandarit605 tsadeeeesstt pake ttd di atas materai lagi ??? 
pict-005 ... adeltw jadi ini tuh buat ngelatih otak kalian gaes $: v$

pict-009 ...riswan7ds1996i Mahmud cntik.

pict-014 indrilukman_new syuudaaahh polooow $<3<3<3<3$

pict-021 ... ryosukeraizel kaga pernah jelek, kaga pernah miskin, kaga pernah susah, anjirenak beud idupnya

pict-053 ayudhialestari21 @ahmad_taupik_akbar_bacakan ajaomdoyegak@ahmad_royuli

pict-054 ... adityasfb love u cuami $<3$ \#31w1dpreganant pict-056 ... araazzahra_sa ae nih

pict-063 ... andini._.id kqkqk juga semangat ya !!!! $<3<3<3<3<3<3$

pict-070 ... rianaendah__ emeeeeeees aneeet $<3<3<3$

pict-071 ...mozhaamn gelaaaseh ${ }^{\wedge} \wedge \wedge$

pict-083 ... fan_fanny19 ttp $g$ bisa klo $g$ julid sama bencess ini

pict-086 ...riaagusnita edisi ke kopel2an kah pict-093 ... salmawidyah siapose ini say ????

pict-095 ...byrn_diazray75 gimik nya ga cihuy , ngerebutin tkg cendol, gelay

Dalam kamus KBBI seharusnya kata tersebut yang benar adalah.

1. pict-001 ...wulandarit605 tsadeeeesstt pake ttd di atas materai lagi ???

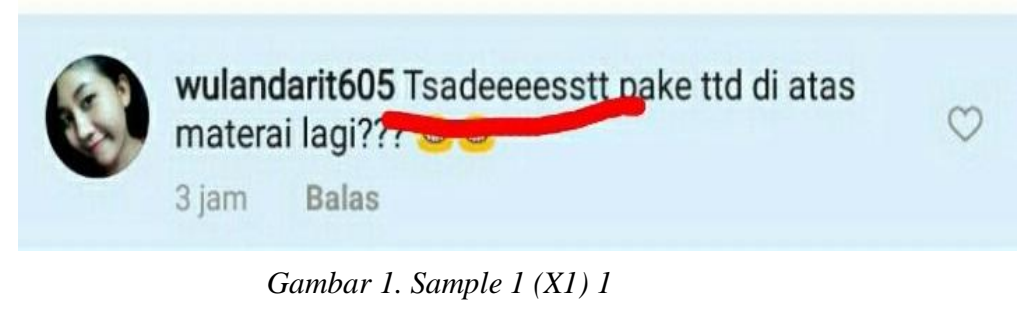

TSADEEEESST $=$ SADIS

$T T D=T A N D A$ TANGAN

2. pict-005 ... adeltw jadi ini tuh buat ngelatih otak kalian gaes :v

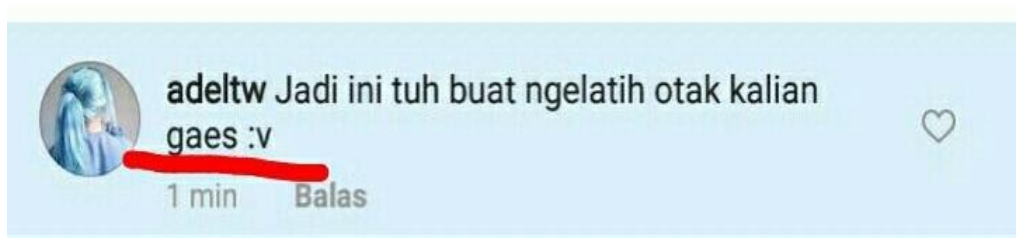

Gambar 2. Sample 2 (X2) 1

$T U H=I T U$

GAES = SEMUA

3. pict-009 ...riswan7ds1996i Mahmud cntik.

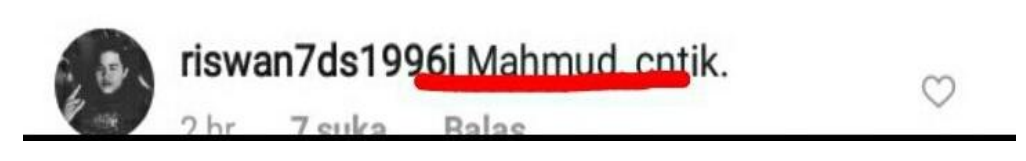

Gambar 3. Sample 3 ( X3 ) 1

MAHMUD $=$ MAMAH MUDA

CNTIK = CANTIK 
4. pict-014 ...indrilukman_new syuudaaahh polooow $<3<3<3<3$

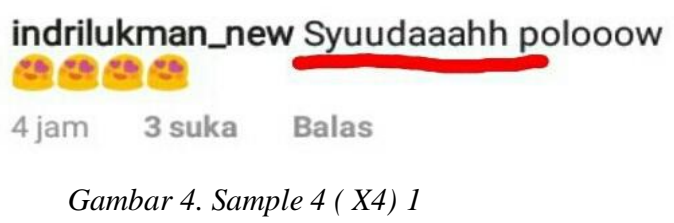

$S Y U U D A A H H=S U D A H$

POLOOOW $=$ FOLLOW

5. pict-021 ... ryosukeraizel kaga pernah jelek, kaga pernah miskin, kaga pernah susah, anjirenak beud idupnya

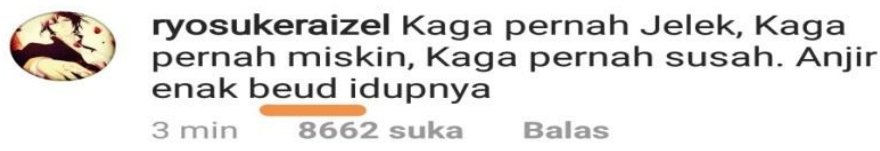

Gambar 5. Sample 5 ( X5) 1

$K A G A=T I D A K$

$A N J I R=$ GILA

$B E U D=B A N G E T$

$I D U P N Y A=H I D U P N Y A$

6. pict-053 ...ayudhialestari21@ahmad_taupik_akbar bacakan ajaomdoye gak @ahmad_royuli

ayudhialestari21

@ahmad_taupik_akbar bacakan
aja omdo hr gak @ahmad_royuli

Gambar 6. Sample 6 ( X6) 1

\section{OMDO =NGOMONG DOANG}

7. pict-054 ...adityasfb love u cuami <3 \#31w1dpreganant

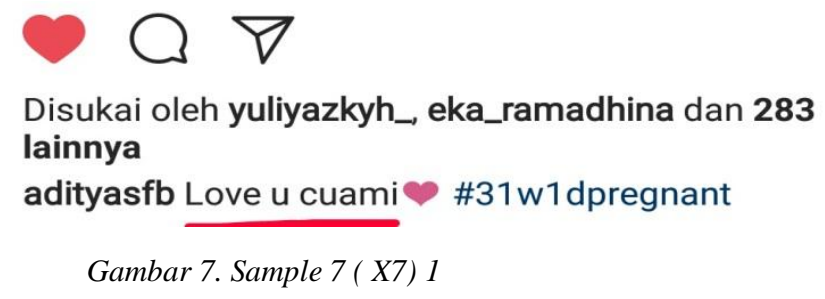

$U=Y O U=K A M U$

$C U A M I=S U A M I$ 
8. pict-056 ...araazzahra_sa ae nih

\section{(0.) araazzahraa_Sa ae nih
43 dtk Balas}

Gambar 8. Sample 8 (X8) 1

$\mathrm{SA}=\mathrm{BISA}$

$\mathrm{AE}=\mathrm{AJA}$

$\mathrm{NIH}=\mathrm{INI}$

9. pict-063 ... andini._.id kqkqk juga semangat ya !!!! $<3<3<3<3<3<3$

andini._.id Kqkqk juga semangat ya!!!!

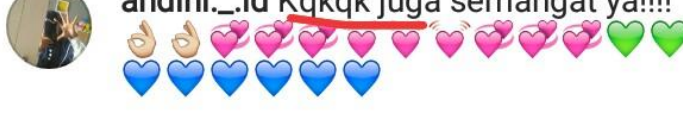

1 jam 1 suka Balas

Gambar 9. Sample 9 ( X9) 1

$K Q K Q K Q=K A K A K$

10. pict-070 ...rianaendah_emeeeeeees aneeet $<3<3<3$

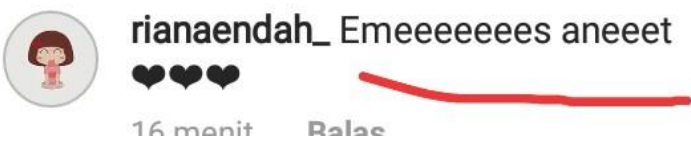

Gambar 10. Sample 10 (X10) 1

EMEEEEES $=$ GEMAS

$A N E E E T=B A N G E T$

11. pict-071 ...mozhaamn gelaaaseh $\wedge^{\wedge} \wedge$

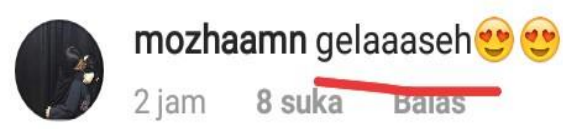

Gambar 11. Sample 11 (X11) 1

GELAAASEH $=$ GILA SIH 
12. pict-083 ...fan_fanny19 ttp g bisa klo g julid sama bencess ini

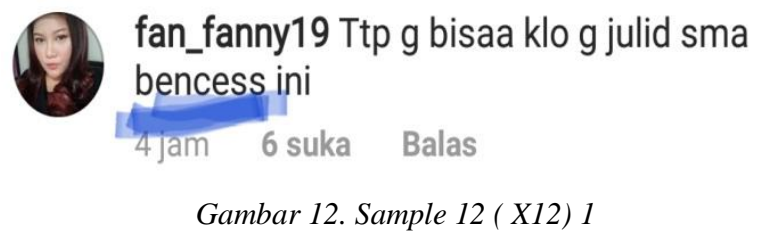

$T T P G=T E T A P T I D A K$

$B E N C E S A=B A N C I$

$K L O=K A L A U$

13. pict-086 ...riaagusnita edisi ke kopel2an kah

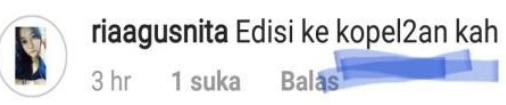

Gambar 13. Sample 13 (X13) 1

KOPEL2AN $=$ COUPLE/PASANGAN

14. pict-093 ... salmawidyah siapose ini say ????

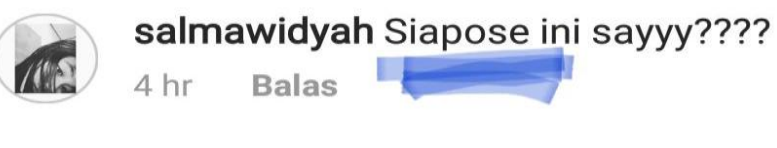

Gambar 14. Sample 14 ( X14) 1

SIAPOSE $=$ SIAPA

15. pict-095 ...byrn_diazray75 gimik nya ga cihuy, ngerebutin tkg cendol, gelay

byrn_diazray75 Gimik nya ga cihuy,

ngerebutin tkg cendol, gelay

$5 \mathrm{hr} \quad 1543$ suka

Gambar 15. Sample 15 ( X15) 1

$C I H U Y=A S I K$

$T K G=T U K A N G$

$G E L A Y=G E L I$

440 | Gustiasari, Dewi Rani. Pengaruh Perkembangan Zaman terhadap Pergeseran Tata Bahasa Indonesia; Studi Kasus pada Pengguna Instagram Tahun 2018 
Berdasarkan contoh-contoh di atas, dapat kita lihat bahwa terdapat satu kesamaan dari bahasa tersebut, yaitu penyingkatan. Bentuk baku bahasa Indonesia tidak digunakan dalam mengetikkan SMS karena bentuk tersebut dirasa terlalu panjang dalam penulisannya. Akhirnya, bahasa Indonesia digantikan dengan singkatansingkatan yang dirasa sudah cukup mewakili sebuah kata. Tidak hanya disingkat dari bahasa Indonesia, tetapi juga digantikan dengan bahasa Inggris yang dirasa lebih singkat dalam penulisannya. Bahkan, bahasa serapan tersebut pun disingkat kembali sampai dirasa satu atau dua huruf saja sudah dapat mewakili suatu kata secara keseluruhan, seperti huruf " $u$ " dalam bahasa Inggris yang pelafalannya mirip dengan kata "you" yang dalam bahasa Indonesia berarti "kamu".

Tanpa kita sadari, kita terus menggunakan bahasa seperti ini dan akhirnya lupa akan bentuk sebenarnya dari bahasa nasional kita. Semakin cepatnya teknologi informasi mendorong kita untuk semakin cepat dalam berkomunikasi yang ditandai dengan penggunaan berbagai bahasa singkatan dan kosa kata baru ini. Akhirnya, kita semakin lupa akan kewajiban kita untuk berbahasa Indonesia yang baik dan benar.Hal ini menyebabkan tergesernya kepopuleran bahasa Indonesia dengan bahasa asing pada tingkat pemakaiannya. Jika hal ini terus kita biarkan, di masa depan tidak ada lagi bahasa Indonesia yang sebenarnya, bahkan mungkin akan tercipta suatu bahasa baru yang akan digunakan secara global oleh masyarakat di era globalisasi sehingga tidak ada lagi perbedaan antar bahasa yang digunakan.

\section{Implikasi pergeseran kata yang digunakan dalam Instagram}

Mengahadapi derasnya laju perkembangan zaman saat ini memang harus di sikapi secara bijaksana.Salah satu implikasi yang di rasakan saat ini yakni pada bahasa nasional Negara Indonesia.Dengan jumlah penduduk yang banyak yang di dukung oleh teknologi yang semakin mahir, masyarakat secara sadar atau tidak sadar telah melakukan pergeseran katakata dalam berkomunikasi sehari-hari.Studi kasus yang diambil saat ini pada media social instagram.

Bahasa Indonesia sangat rentan terhadap pengaruh globalisasi, baik itu mendapatkan pengaruh positif ataupun negatif.

\section{Dampak Positif}

a) Bahasa (alay atau gaul) Indonesia mulai dikenal oleh dunia internasional.

Terlepas dari itu bahasa alay atau gaul yang konotasinya negatif, terbukti bahwa kemampuan berbahasa masyarakat Indonesia khusunya di media sosial berhasil mengundang rasa ketertarikan. Salah satu contohnya seperti Indonesia is wkwk land. Wkwk Land adalah bahasa Alay yang viral di dunia Internasional.

\section{Dampak Negatif}

a) Masyarakat Indonesia tidak menggunakan bahasa Indonesia yang baik dan benar. Banyak masyarakat Indonesia yang berkomunikasi via instagram lebih merasa bangga dan membanggabanggakan menggunakan bahasa negeri orang lain. Atau malah mencampur-campur bahasa indonesia dengan bahasa asing. Sehingga banyak memunculkan bahasa serapan dari kata bahasa asing menjadi di- bahasa Indonesia kan.

b) Berkurangnya minat generasi muda untuk mempelajari Bahasa Indonesia yang baik dan benar. Generasi muda cenderung untuk lebih menyukai sesatu yang modern atau maju dalam berkomunikasi. Dengan masuknya budaya-budaya asing dan bahasanya tentu lebih menarik bagi sebagian besar generasi muda untuk dipelajari.

c) Memberi efek rancu akan Kosakata Bahasa Indonesia yang baik dan benar. Bagi sebagian besar pengguna media sosial, lebih mengerti arti dari bahasabahasa alay dibanding dengan Kosakata Bahasa Indonesia yang baik dan benar.

d) Bisa mengancam kedudukan Bahasa Indonesia sebagai bahasa Negara. Lama kelamaan Bahasa Indonesia akan terkikis oleh generasi muda yang justru lebih mengembangkan bahasa-bahasa alay atau gaul 


\section{PENUTUP}

\section{Kesimpulan}

Dari data yang telah ada, ternyata dalam penggunaan bahasa gaul di media social Instagram dalam komunikasi tidak langsung yang dilakukan oleh pengguna yang masih berusia remaja. Dalam situasi nonformal pada saat meyampaikan pesan lewat akun instagram pribadi mereka dalam berinteraksi dengan teman sebaya mereka diperoleh data sebagai berikut.

Bahasa gaul berdasarkan jenis slang yang digunakan untuk berkomunikasi di dalam media sosial instagram terdapat beberapa jenis seperti jargon yang merupakan frase atau kalimat pendek yang dipopulerkan oleh orang-orang yang memiliki pengaruh besar seperti pimpinan negara, artis, dan tokoh-tokoh dalam bidang tertentu. Ada juga prokem Suatu bentuk bahasa slang yang proses dalam pembentukanya dengan cara afiksasi, membalikan susunan kata, dan dengan memberi suatu sisipan. dan colloqial, yaitu penggunaan bahasa yang disingkat sehingga berkurannya fitur linguistik dalam kalimat tertentu. Sementara itu makna kosakata slang yang terdapat dalam media sosial facebook memiliki arti atau makna tertentu yang dikaji berdasarkan analisis sosiolinguistik.

\section{Saran}

Bahasa gaul atau slang selalu berkembang dari waktu kewaktu, itu berarti bahwa setiap tahun akan ada beberapa kata-kata gaul baru yang dikembangkan dan digunakan oleh orangorang. Tingkat pengguna media sosial yang semakin tinggi dari waktu kewaktu. Membuat cara berkomunikasi menjadi semakin, sederhana, cepat, dalam mengakses komunikasi yang dibutuhkan. Penggunaan bahasa gaul yang disisipkan dalam komunikasi mengunakan bahasa Indonesia adalah salah satu cara untuk membuat komunikasi yang cepat dan sederhana. Dalam penelitian ini, kata-kata gaul dalam bahasa Indonesia yang dikumpulkan hanya dari instagram), dan bagian-bagian yang dianalisis adalah jenis slang dan makna slang dalam penggunaannya di media sosial instagram. Ada beberapa aspek di balik penggunaan kata-kata slang; seperti penggunakan bahasa gaul tertentu dalam kelompok khusus yang tidak hanya terjadi dalam media sosial instagram. Karena alasan ini, peneliti ingin menyarankan beberapa bagian mengenai bahasa gaul yang layak diselidiki, oleh peneliti berikunya yang ingin menggarap penelitian mengenai bahasa gaul adalah sebagai berikut:

1. Menganalisis penggunaan kata-kata bahasa gaul dalam komunitas tertentu.
2. Menyelidiki faktor-faktor yang menyebabkan seseorang untuk menggunakan kata-kata gaul.

3. Menganalisis kata-kata gaul dalam sastra atau film

\section{DAFTAR PUSTAKA}

Aminudin. (2011). Semantik (Pengantar Studi Tentang Makna). Bandung: Sinar Baru Algensindo.

Chaer,Abdul dan Agustina, Leonie. (2004). Sosiolinguistik : Perkenalan Awal. Jakarta; Rineka Cipta.

Depdikbud. (2002). Kamus Besar Bahasa Indonesia.Jakarta: Balai Pustaka.

Nina Nurhasanah. (2014). "Pengaruh Bahasa Gaul Terhadap Bahasa Indonesia". Forum Ilmiah, 11 (1). 